\title{
Evidence of high-temperature rock salt transformations in areas of occurrence of borate minerals (Zechstein, Kłodawa salt dome, Poland)
}

\author{
Tomasz TOBOŁA ${ }^{1, *}$ and Jacek WACHOWIAK ${ }^{2}$
}

\author{
1 AGH University of Science and Technology, Faculty of Geology, Geophysics and Environmental Protection, \\ Al. A. Mickiewicza 30, 30-059 Kraków, Poland \\ 2 Geosalt - Badania i ekspertyzy geologiczne złóż soli, Rzepichy 42, 30-240 Kraków, Poland
}

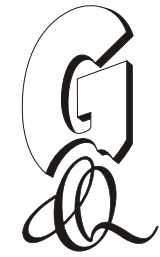

Toboła, T., Wachowiak, J. 2018. Evidence of high-temperature rock salt transformations in areas of occurrence of borate minerals (Zechstein, Kłodawa salt dome, Poland). Geological Quarterly, 62 (1): 134-145, doi: 10.7306/gq.1390

\begin{abstract}
Occurrences of borate minerals in the Zechstein salt-bearing deposits of the Kłodawa salt dome (central Poland), and the manner of their development, suggest that the minerals were formed at high temperatures, that considerably exceed the temperature estimated from the thermal gradient $\left(\sim 180^{\circ} \mathrm{C}\right)$. Research on rock salt and potassium-magnesium salts containing congolite and boracite, respectively, are consistent with high-temperature processes of transformations affecting the salt rocks in certain sections of the salt dome. The chemical composition of, and daughter minerals occurring in, primary fluid inclusions in halite, originating from the congolite zone, indicated a very high proportion of potassium and magnesium in the brines from which the halite crystallised. The thermal transformations observed in inclusions indicate a halite crystallisation temperature exceeding $420^{\circ} \mathrm{C}$. Anhydrite crystals, co-occurring with borate minerals, represent unique features as to the distribution and composition of solid and fluid inclusions. These features indicate crystallisation or recrystallisation in conditions that differed considerably from those typical of the salt dome, with the involvement of solutions of changing chemical compositions. The crystals contain multiple solid inclusions of transparent and non-transparent minerals, among which we have focused on carnallite. The relationships of carnallite with liquid and gaseous phases indicate, as in the congolite zone, migration of very highly concentrated brines with respect to potassium and magnesium, or even transport of carnallite in the form of melt (liquid). Measurements of fluid inclusion homogenization temperatures, within the range from 197.8 to $473.8^{\circ} \mathrm{C}$, supported a high-temperature origin for these minerals in hydrothermal conditions.
\end{abstract}

Key words: Zechstein, salt deposit, hydrothermal conditions, borates, fluid inclusions.

\section{INTRODUCTION}

The minerals and evaporite rocks within salt dome structures are commonly so strongly transformed that their composition is different from their original one, owing to sea water evaporation. The degree of such change depends on transformations during diagenetic and subsequent tectonic processes. In particular, such hydrated minerals as gypsum, carnallite, epsomite, kieserite, and langbeinite are susceptible to temperature and pressure changes (e.g., Borchert and Muir, 1964; Łaszkiewicz, 1967; Stańczyk, 1970, 1971; Stańczyk-Stasik, 1976; Sonnenfeld, 1984). The decomposition of those minerals at increasing temperatures and pressures releases considerable quantities of water which, being a good polar dissolvent, reacts with minerals and dissolves them. The migration of the resultant solutions within the salt-bearing deposits causes ion exchange reactions with the host rocks and the crystallisation of epigenetic minerals. Another factor which enhances mineral

* Corresponding author, e-mail: tob@geolog.geol.agh.edu.pl Received: July 12, 2017; accepted: October 12, 2017; first published online: November 21, 2017. transformation processes is the release of solutions from fluid inclusions.

Among the evaporite deposits of the Kłodawa salt dome and of other salt domes in Poland (Mogilno or Inowrocław) there occur minerals or their parageneses whose presence is difficult to explain. Their occurrence cannot be explained by sedimentation, diagenetic or epigenetic processes resulting from the burial of the Zechstein salt-bearing formation, or by tectonic activity during development of the salt domes. These phenomena include, for example, zones of borate mineral occurrences (boracite and congolite) in rock salt and in potassium-magnesium salts (Wachowiak and Pieczka, 2012; Wachowiak and Toboła, 2014). The form of occurrence of those minerals as cubic blocks (congolite) or regular polyhedra (boracite) indicates that they crystallised in regular systems and in high-temperature conditions. Laboratory studies on phase transitions in artificially formed and natural borate minerals clearly determine the temperatures above which those minerals crystallise in a regular system (for congolite: $339^{\circ} \mathrm{C}$ and for boracite: $270^{\circ} \mathrm{C}$ - Burns and Carpenter, 1996, 1997; Wachowiak and Toboła, 2014). "Blue halite" veins represent another type of salt rock altered at high temperatures (Toboła, 2016). Based on microthermometric determinations of fluid inclusions in anhydrite that occur in the coloured halite, temperatures of up to $513^{\circ} \mathrm{C}$ were estimated (Toboła, 2016). In both cases the ranges of those tem- 
peratures considerably exceed the values related to the geothermal gradient, i.e. the maximum depth to which a salt-bearing formation could have been buried.

Previous study (Wachowiak and Pieczka, 2012; Wachowiak and Toboła, 2014) concerned the boracite minerals from Kłodawa salt dome and their phase transformation. The purpose of the present study was to check whether factors indicating high-temperature rock transformation have been preserved in the salt-bearing rocks containing borate minerals. Such indicators have already been identified in microthermometric studies of fluid inclusions that gave a reliable picture of the temperature and pressure conditions and chemical composition of the solutions from which crystallisation started (e.g., Roedder, 1984a; Goldstein and Reynolds, 1994). Petrological and microthermometric study has been carried out on halite and anhydrite crystals.

\section{GEOLOGICAL SETTING}

The Kłodawa salt dome is one of several tens of salt structures occurring in the Polish Lowlands (Fig. 1). It is situated at the SW edge of the Mid-Polish Trough (e.g., Dadlez, 1989, 2001; Dadlez et al., 1995; Krzywiec, 2004, 2006; Krzywiec et al., 2017). The salt dome is a fragment of a large tectonic salt structure stretching from Łęczyca near Łódź to Izbica Kujawska (Werner et al., 1960; Burliga et al., 1995; Krzywiec, 2004). The longer axis of the whole structure and of the salt dome is parallel to the position of the Mid-Polish Trough, in an approximate SE-NW direction.

The rising salt rocks pierced through the Mesozoic cover over a distance of $\sim 26 \mathrm{~km}$ and a width of $2 \mathrm{~km}$. They create a form of a tectonic horst, leaning from NE to SW. The evaporite layers are steep, at angles of $70-85^{\circ}$. The salt-bearing succession is built of the evaporites of four cyclothems: PZ1, PZ2, PZ3, and PZ4 (Fig. 2). The PZ2 and PZ3 cyclothems are complete, classical evaporite sequences that consist of the following deposits: terrigenous deposits, carbonates, sulphates, rock salt and potassium-magnesium salts. The rocks of cyclothem PZ1 are partly uncovered in the Kłodawa salt dome, but their stratigraphic position is uncertain (Werner et al., 1960; Kucia, 1970; Burliga et al., 1995).

In the bottom part of the PZ4 cyclothem no typical terrigenous or carbonate deposits are present. Two thick units of evaporite-terrigenous salts, the so-called zubers, each $>100 \mathrm{~m}$ thick, comprising the upper parts of the PZ3 and PZ4 cyclothems, are characteristic of the Upper Permian salt succession of the Kłodawa salt dome.

Halokinetic (Trusheim, 1957) and halotectonic processes (Poborski, 1970, 1971, 1974) associated with diapirism resulted in extensive mechanical deformations of the salt layers. The evaporite rocks and minerals were also subjected to metasomatic, diagenetic, and metamorphic alterations. The primary parent alkali "enclosed" in the salt dome, or alkali originating from the inflow of external water, or residual alkali originating from the metamorphism and/or melting of less resistant salt minerals played a considerable role in the geochemical

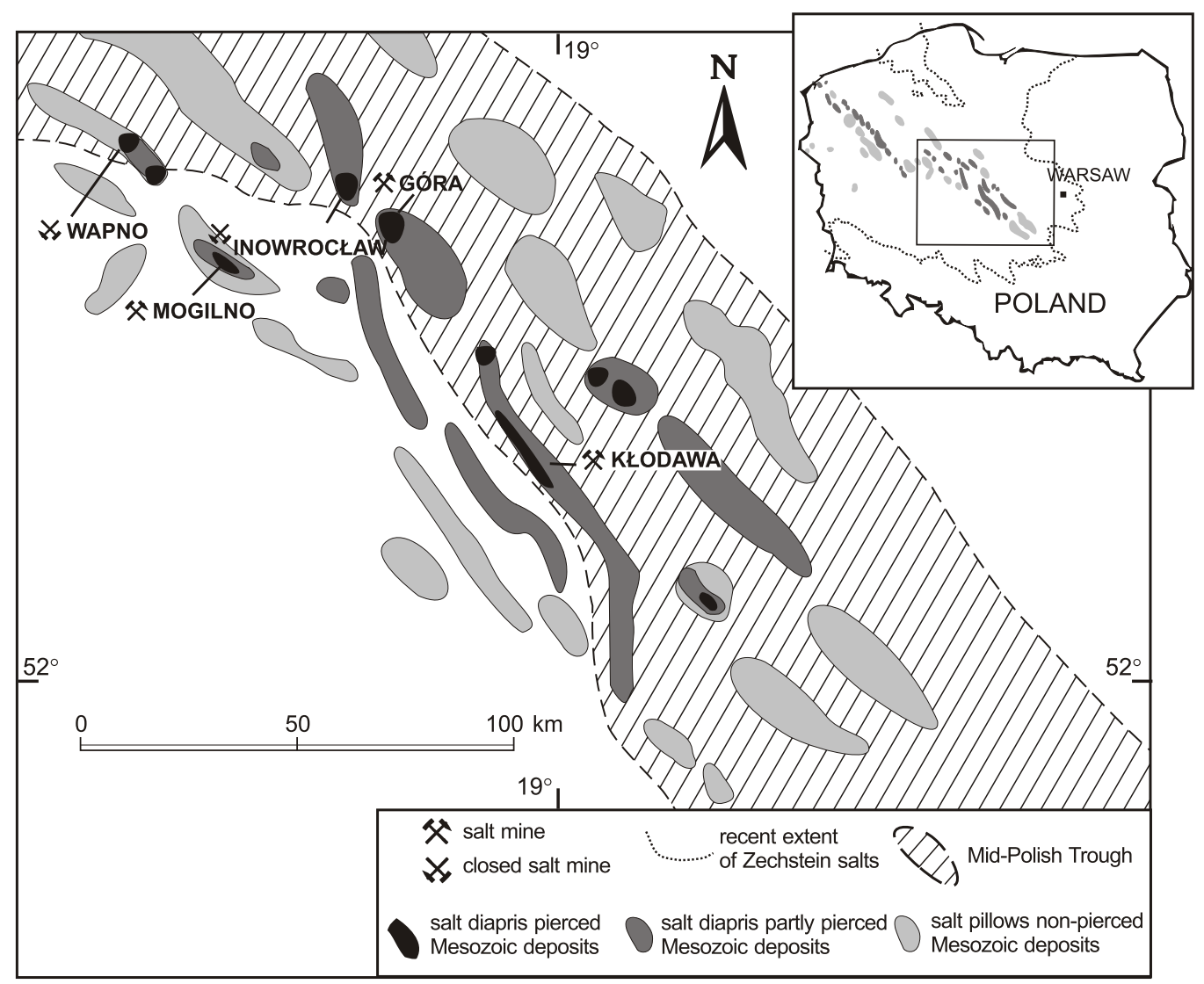

Fig. 1. Part of a Zechstein lithofacies map and the location of salt structures in the Łódź-Konin area (after Garlicki and Szybist, 1986) 


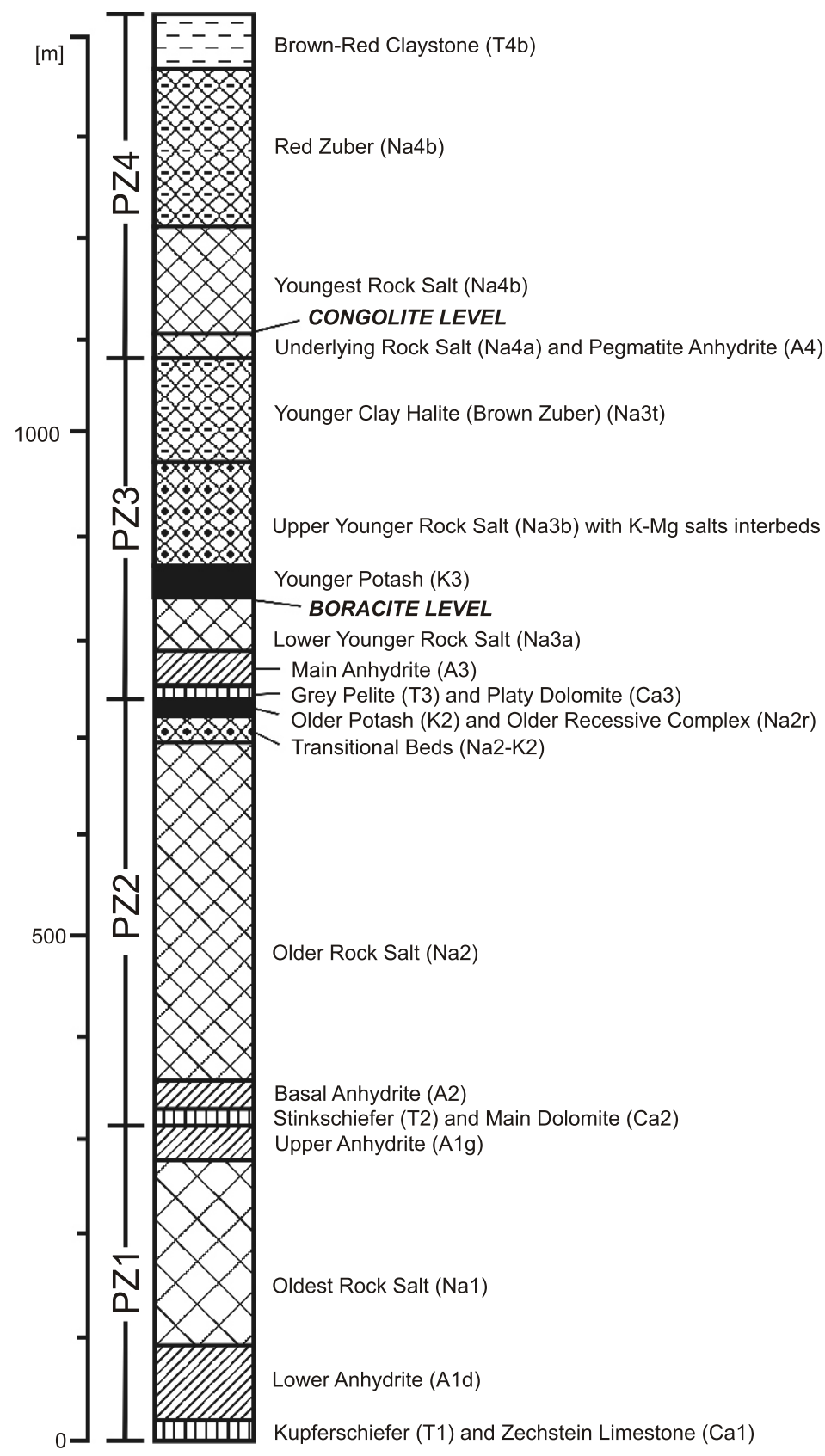

Fig. 2. Generalized lithostratigraphic cross-section through the Zechstein salt-bearing succession of the Kujawy region (after Garlicki and Szybist, 1991)

transformation processes. Such solutions used voids, fissures, and dislocation zones to penetrate the whole salt dome mass. High temperatures and pressures in deeper and some higher salt dome sections were the main stimulators of those processes.

\section{METHODS}

Anhydrite and celestine crystals were leached out, together with borate minerals, from 15 samples collected from level 750 of the Kłodawa Salt Mine (Wachowiak and Toboła, 2014). Thirty crystals 0.6 to $2 \mathrm{~mm}$ in size were selected from these samples, after preliminary selection under a binocular microscope. They had smooth surfaces allowing for direct microscopic observations of inclusions. Twenty other individual crystals characterized by coarse surfaces and the presence of fluid inclusions were selected. Thick sections (thickness $\sim 200 \mu \mathrm{m}$ ) were prepared.

The fragments of rock salt in which congolite was identified were cut into $2 \mathrm{~mm}$ thick plates (Wachowiak and Toboła, 2014). The salt samples were cut by a Struers Minitom slow-speed saw. Later, the plates were grounded and polished on both sides. In the case of the larger halite crystals, slides were received as a result of splitting up along the cleavage surfaces.

The analysis of fluid inclusions, including investigation of the homogenization temperature in the anhydrite crystals, was carried out under a Nikon Eclipse E600 polarizing microscope, equipped with $5 x, 10 x$, 20x, 50x, and 100x lenses. A UV $365 \mathrm{~nm}$ wavelength lamp was used for additional external lighting. The microscope was equipped with a THMSG 600 replaceable freezing-heating table, with Linkam accessories, that enabled temperature measurements in the range from -196 to $600^{\circ} \mathrm{C}$, with an accuracy of up to $0.1^{\circ} \mathrm{C}$. Before the temperature measurement, the stage was calibrated by pure $\mathrm{H}_{2} \mathrm{O}-\mathrm{CO}_{2}$ synthetic inclusions $(\mathrm{Tm}=$ $-56.9^{\circ} \mathrm{C}$ ), and pure $\mathrm{H}_{2} \mathrm{O}$ inclusions (critical density of $\mathrm{Tm}_{\text {ice }}=0.0^{\circ} \mathrm{C}, \mathrm{Th}=374^{\circ} \mathrm{C}$ ).

Chemical analyses of the anhydrite and celestine were performed using a JEOL SuperProbe JXA-8230 electron microprobe (EMP) at the Laboratory of Critical Elements at the University of Science and Technology, Kraków. The EMP was operated in the wavelength-dispersion mode at an accelerating voltage of $15 \mathrm{kV}$, a probe current of $20 \mathrm{nA}$ for anhydrite and $15 \mathrm{kV}$ and $15 \mathrm{nA}$ for celestine, as a focused beam with a diameter of $10 \mu \mathrm{m}$. Counting times of $10 \mathrm{~s}$ on peaks and $5 \mathrm{~s}$ on both $(+)$ and $(-)$ backgrounds were used. The following standards, lines and crystals were used: Kyanite (AlK $\alpha$, TAPH), barite (SK $\alpha, \mathrm{PETL}$; BaL $\alpha, \mathrm{PETL})$, calcite (CaK $\alpha, \mathrm{PETH}), \mathrm{KBr}(\mathrm{KK} \alpha, \mathrm{PETH}), \mathrm{MgO}(\mathrm{MgK} \alpha$, $\mathrm{TAPH}), \mathrm{SrSO}_{4}(\mathrm{SrK} \alpha, \mathrm{PETJ})$.

\section{RESULTS}

\section{SOLID INCLUSIONS IN HALITE CRYSTALS FROM THE AREA OF THE CONGOLITE OCCURRENCE}

The halite crystals, which build the parent rock of the congolite, contain numerous anhydrite ingrowths and various types of fluid inclusion assemblages. The distribution of anhydrite ingrowths varies. In the case of salt that is macroscopically white or light pink in colour, the ingrowths create streaks composed of loosely distributed individuals, easily visible only with crossed polars (Fig. 3A, B). The ingrowths are concentrated mainly at the halite crystal boundaries, less often they occur as streaks or single discordant individuals. The size of single ingrowths ranges from several dozen micrometres to $\sim 0.5 \mathrm{~mm}$. The intergrowths are mostly anhedral with cylindrical or occasionally round shapes (Fig. 3C). Less often, there are subhedral and anhedral crystals (Fig. 3D).

The occurrence of surface inclusions is a characteristic feature observed in all the samples. The size of these inclusions ranges from several to about $\sim 10 \mu \mathrm{m}$, occasionally, they reach $30 \mu \mathrm{m}$ (Fig. 3D). Small inclusions are cylindrical or round, while the larger ones are characterized by irregular shapes. The inclu- 

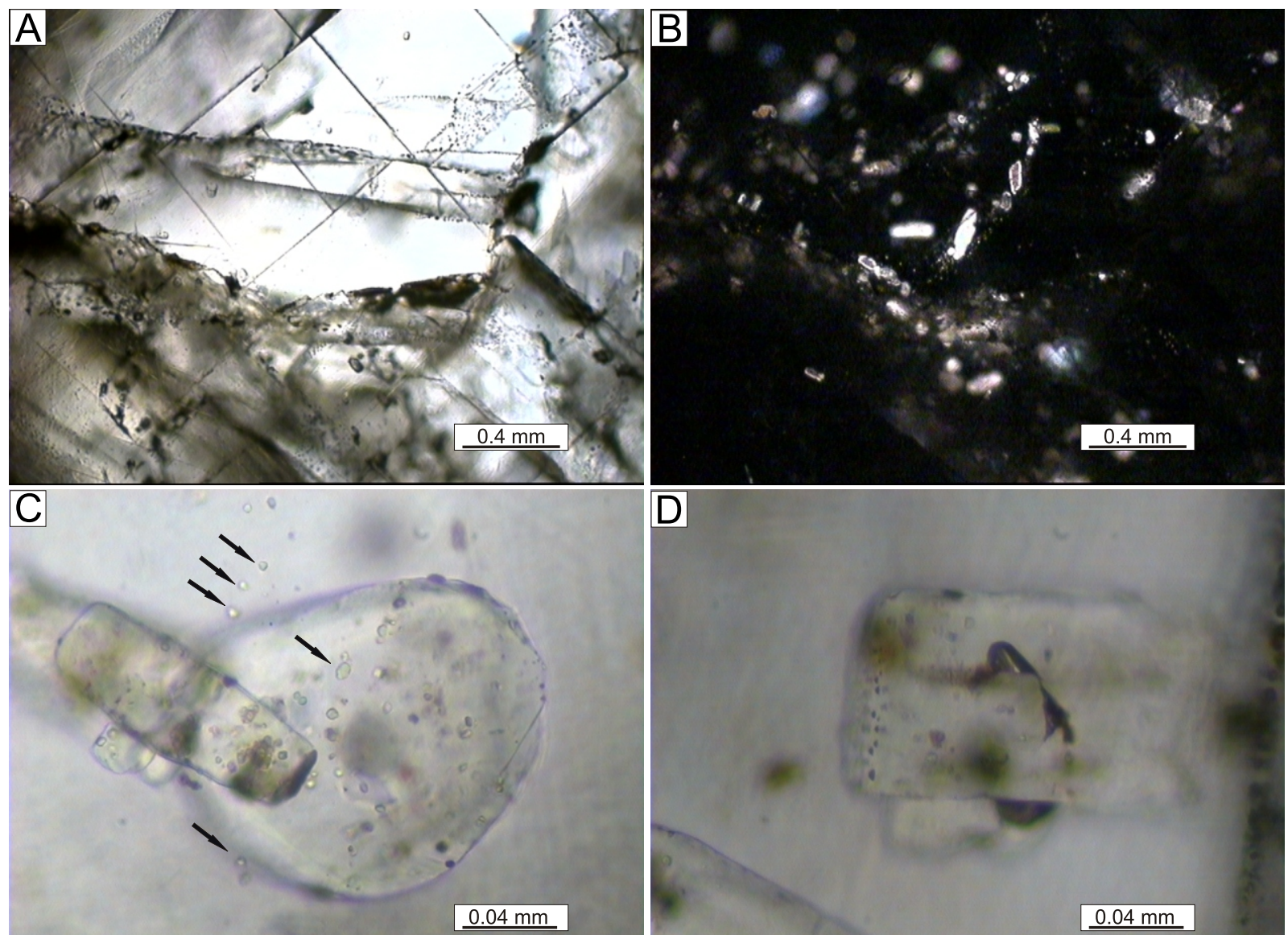

D
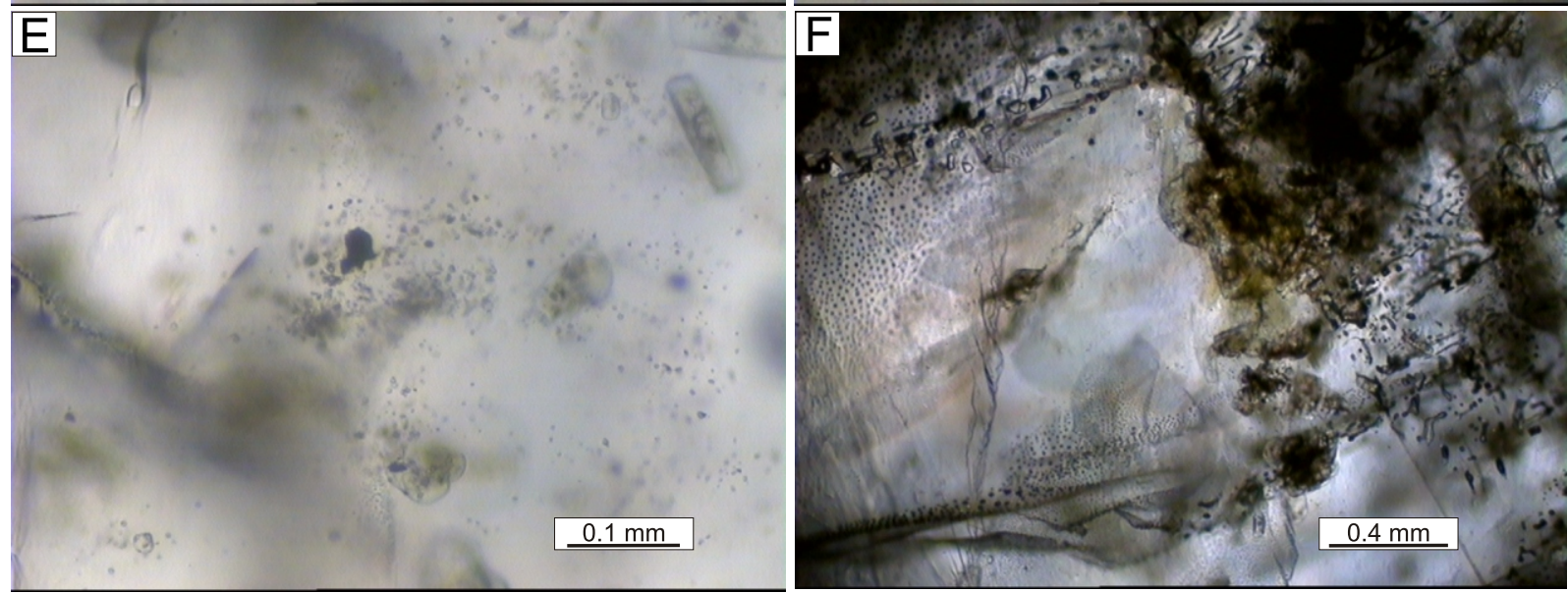

Fig. 3. Microscopic images of "thick" plates

A, B - anhydrite concentrations and fluid inclusion assemblages, within white and pink rock salt ( $-1 \mathrm{~N}, \mathrm{~B}-\mathrm{XN})$; C - co-occurring anhydrite crystals, of anhedral and euhedral shape $(1 \mathrm{~N})$; they are surrounded by very fine discordant anhydrite crystals (marked by arrows); D - anhydrite crystals with fine inclusions on their surfaces (black points), with a composition that is hard to identify and two large gas inclusions $(1 \mathrm{~N})$; $\mathrm{E}$ - concentration of very fine anhydrite crystals accompanied by a brownish substance $(1 \mathrm{~N}) ; \mathbf{F}$ - larger concentrations of anhydrite flasers in grey-brown salt $(1 \mathrm{~N})$

sions are filled with a gaseous phase, locally with a small participation (several \%) of a liquid phase. Quite often, a brownish substance of organic origin appears on anhydrite crystal surfaces. The substance does not cause excitation in UV light. It creates blurred and irregular flasers and concentrations (Fig. 3C, D).

The anhydrite also forms very small crystals with several micrometres in size. They have anhedral and round shapes
(Fig. 3C, E). Such anhydrite crystals appear either within the anhydrite concentrations noted above or accompany single larger crystals, and locally they occur in the places where halite crystals seem to be pure. Single crystals of that type, evenly distributed in halite, as well as mostly occurring with flasers of larger crystals, have pure surfaces. They are less often accom- 
panied, mostly when they create larger and more compact concentrations, by a brownish substance (Fig. 3E).

There are more anhydrite concentrations and streaks in those fragments of rocks which are macroscopically coloured grey-brown. Anhydrite crystals are packed densely there, contacting each other, and generally possessing larger dimensions (Fig. 3F). They are accompanied by larger quantities of brown material and in places they create concentrations among anhydrite crystals.

Besides anhydrite there occurs very rarely celestine. It forms euhedral to subhedral crystals the range of several to hundreds of micrometres in size. Locally within large celestine crystals, an anhydrite ingrowth occurs (Fig. 4).

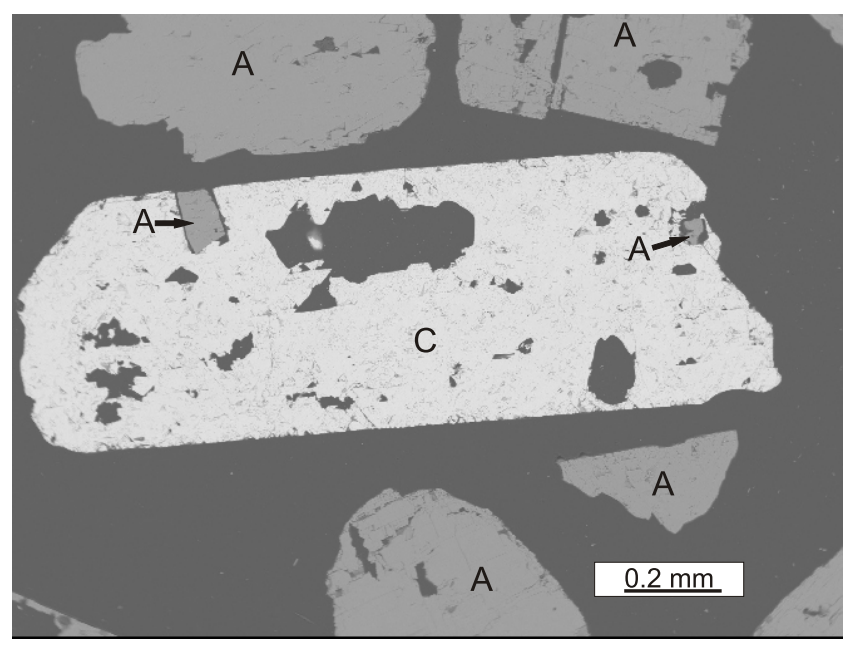

Fig. 4. SEM-EDS image of celestine crystals with small anhydrite inclusions ( $\mathrm{A}$ - anhydrite, $\mathrm{C}$ - celestine)

\section{FLUID INCLUSIONS IN HALITE CRYSTALS}

Genetically, two types of fluid inclusion assemblages (FIA) can be distinguished within the halite studied: secondary (or pseudo-secondary) and primary assemblages (e.g., Roedder, 1984a, b; Goldstein and Reynolds, 1994; Goldstein, 2001; Petrychenko and Peryt, 2004; Kovalevych et al., 2006, 2009; Kovalevych and Vovnyuk, 2010). Most often, the secondary inclusion assemblages occur in halite crystals, although some may have formed during recrystallisation processes (pseudo-secondary FIAs). Locally, inclusions are distributed in dense concentrations characterized by complex courses and diverse spatial relationships (Fig. 5A).

FIAs occur both at halite crystal boundaries and within crystals. They form rows running as almost straight or wavy lines. Particular assemblages run in parallel or almost parallel, cross-cutting each other or splitting off from one point (Fig. 5B). In many cases, the co-occurrence (overlapping) of many different petrological types of inclusions in one row may be observed. Gradual disappearance of FIA courses within the halite crystals as well as gradual decrease in their dimensions is common. It is characteristic of FIAs composed of very small inclusions (Fig. 5B, C).

The size of fluid inclusions varies from $\sim 1$ to $>200 \mu \mathrm{m}$ depending on the FIA (Fig. 5D, E). The shapes of inclusions are mostly regular, isometric, cubic, cylindrical, and almost round.
Larger inclusions occasionally have elongated, tubular shapes (Fig. 5D). Inclusions with irregular shapes are more rare that regular ones (Fig. 5E).

In most cases, inclusions are filled only with a gaseous phase, or the liquid phase creates a very thin film at the boundaries (the film is often hard to identify in petrographic studies). Liquid-gas inclusions, with changeable phase proportions, occur less often, though the gaseous phase usually dominates volumetrically in inclusions. Inclusions that are filled completely with the liquid phase are very rare and occur only in a small portion of FIAs.

Primary FIAs occur rarely in the crystals analysed. This type of inclusions was developed somewhat differently than the typical sedimentation inclusions assemblages (e.g., Roedder, 1984a, b; Goldstein and Reynolds, 1994; Benison and Goldstein, 1999; Warren, 1999; Kovalevych and Vovnyuk, 2010). The primary inclusions form zones (areas) in central parts of the crystals. The size of inclusions ranges from 2 to $20 \mu \mathrm{m}$. Locally larger inclusions, with a cubic shape occur (Fig. 5F). They are different than the typically developed primary halite inclusions with respect to the presence of daughter minerals that indicate a relatively large double refraction index. These minerals occur in all inclusions, in the dimensions that are proportional to the inclusion sizes. When heated to $397^{\circ} \mathrm{C}$, the minerals started to gradually melt and at $420^{\circ} \mathrm{C}$ they were completely dissolved in all inclusions.

\section{INCLUSIONS IN ANHYDRITE CRYSTALS}

The anhydrite crystals, leached out with borate minerals from rock salt and potassium-magnesium salts, are characterized by atypical shapes, resulting from crystal transformations. Moreover, anhydrite crystals contain several types of inclusions which differ in distribution with respect to the mineral axis of the host mineral, dimensions, and primarily the filling material. Those inclusions occur in changeable quantities and they are distributed irregularly in particular crystals.

In the anhydrite crystals separated from rock salt containing congolite, the most uniformly shaped type of FIA, with respect to inclusion dimensions and shapes, is relatively frequent. FIAs form bands with straight courses in the middle sections of crystals (Fig. 6A). The bands rarely cover the whole crystal, and their thickness is up to $20 \mu \mathrm{m}$. They are composed of densely packed, very small inclusions $\sim 1 \mu \mathrm{m}$ in size which should be recognized as primary owing to their location with respect to the crystal.

The external sections of crystals, as well as the crystals which do not contain that type of fluid inclusions are mostly transparent (Fig. 6A). The crystals contain mainly elongated and cylindrical solid or solid-gas inclusions, with marked dominance of the solid phase. Their longer dimensions reach up to $50 \mu \mathrm{m}$ and they are $30 \mu \mathrm{m}$ wide. The solid inclusions are filled with a transparent mineral phase, with another double refraction index than the host mineral. These inclusions undergo characteristic transformations ("melting") during heating. This process is discussed in detail below in the case of the anhydrites leached out from potassium-magnesium salts originating from the boracite zone where similarly developed inclusions occurred.

Fluid inclusions (liquid-gas) occurred very rarely in the crystals studied, in the form of single individuals with dimensions of several millimetres. Their positions and petrological features made it impossible to carry out reliable homogenization temperature measurements. 

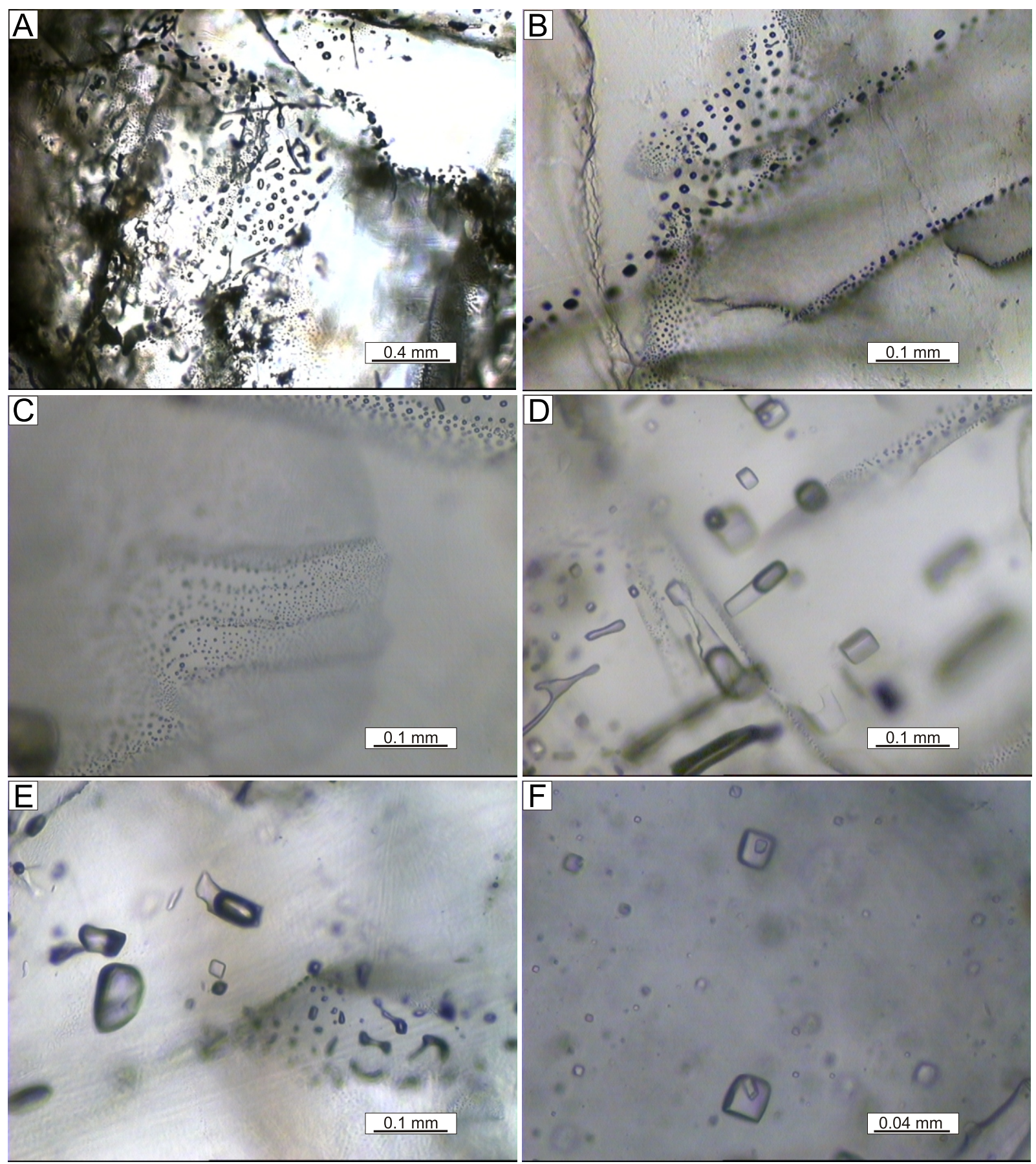

Fig. 5. Microscope images (1N) of inclusions in halite

A - concentrations of secondary fluid inclusion assemblages in halite; B - co-occurring assemblages of large and very fine inclusions, mainly filled with a gas phase, with parallel and crossing courses; some assemblages indicate losses of the courses; C characteristic disappearance of an assemblage of very fine inclusions within a halite crystal; D - three inclusion assemblages. In the upper right corner, part of a disappearing assemblage of very fine gas inclusions; in the central section, an assemblage of large inclusions, with changeable phase proportions and elongated inclusions; on the left-hand side, a fragment of an inclusion assemblage with irregular shapes; $\mathbf{E}$ - inclusions with irregular shapes, liquid-gas and gas inclusions; $\mathbf{F}$ - an assemblage of primary inclusions with daughter minerals

Densely packed primary inclusions were not found within the anhydrite crystals occurring in the potassium-magnesium salt containing boracite, as was the case of anhydrite crystals co-occurring with congolite. However, there were many more fluid inclusions. These inclusions displayed strongly elongated and tubular shapes (Fig. 6B). They were arranged with their longer axes in parallel to each other and also parallel to the crystallographic axes. The longer axes of inclusions reached up to $400 \mu \mathrm{m}$, with the width from 1 to $5 \mu \mathrm{m}$. These were liquid-gas inclusions, mostly with the liquid phase dominant. The phase proportions were relatively stable in particular crystals or their sections, although there were considerable differences be- 

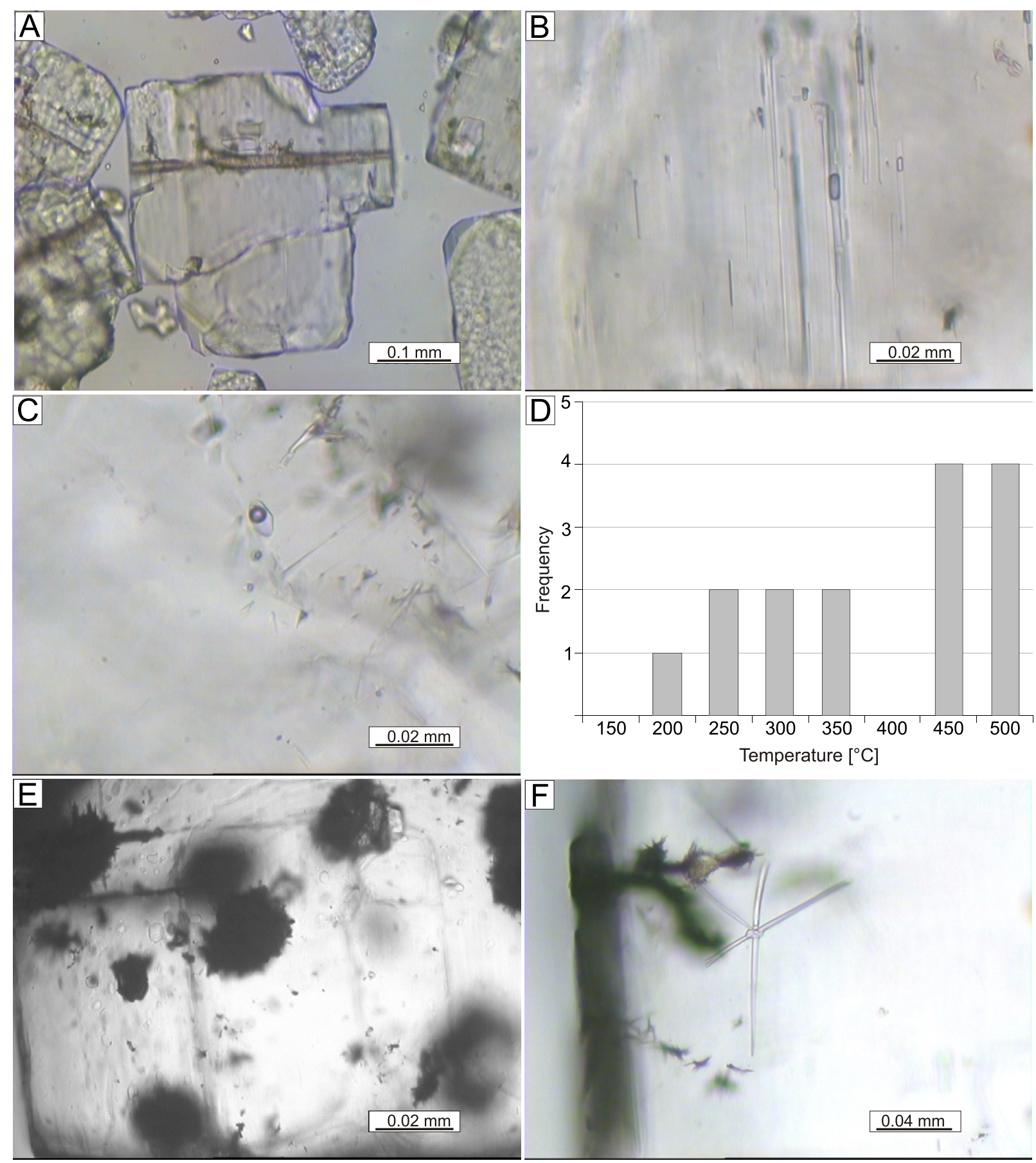

Fig. 6. Microscopic images of anhydrite crystals

A - relic of a primary inclusion assemblage in an anhydrite crystal (dark band in the central section of the crystal), surrounded by a transparent lining containing (1N); B - elongated liquid-gas inclusions with uneven phase proportions (1N); C - liquid-gas inclusions with cylindrical shapes and stable phase proportions $(1 \mathrm{~N})$; $\mathbf{D}$ - histogram of temperatures of homogenization; $\mathbf{E}-$ concentrations of round, non-transparent mineral assemblages occurring within an anhydrite crystal; $\mathbf{F}$ - ingrowths of transparent minerals with needle-like habit; these minerals probably crystallised just before anhydrite and were overgrown by anhydrite

tween the inclusions originating from different anhydrite crystals. Inclusions with more isometric cylindrical shapes were observed less frequently (Fig. 6C). Moreover, some inclusions of that type contained fixed phase proportions.

Homogenization temperatures could be measured for those FIAs with fixed phase proportions (vapour volume $\sim 30 \%$ ); however, for the anhydrite crystals studied this was possible only in fifteen cases (Table 1). The values obtained vary from 197.8 to $473.8^{\circ} \mathrm{C}$, and the temperatures belong to two ranges (Fig. 6D), with temperatures ranging up to $350^{\circ} \mathrm{C}$ being less common. The higher temperature range (i.e. $>400^{\circ} \mathrm{C}$ ) has a frequency of 4 . In general, homogenization proceeded towards the liquid phase, though in one of the inclusions we also found homogenization towards the gas phase, at $\sim 350^{\circ} \mathrm{C}$. In 
Ta ble 1

Homogenization temperatures of inclusions in the anhydrite crystals

\begin{tabular}{|c|c|}
\hline Sample no. & $\begin{array}{c}\text { Homogenization } \\
\text { temperature } \operatorname{Th}\left[{ }^{\circ} \mathrm{C}\right]\end{array}$ \\
\hline \multirow{2}{*}{$a b 01$} & 347.1 \\
\hline & 455.6 \\
\hline$a b 08$ & 318.6 \\
\hline \multirow{2}{*}{$\mathrm{a} 01$} & $350.0^{*}$ \\
\hline & 414.0 \\
\hline $\mathrm{a} 02$ & 237.7 \\
\hline \multirow{2}{*}{ a03 } & 272.7 \\
\hline & 286.0 \\
\hline \multirow{2}{*}{ a05 } & 249.6 \\
\hline & 197.8 \\
\hline \multirow{7}{*}{ a06 } & 422.3 \\
\hline & 414.7 \\
\hline & 434.2 \\
\hline & 452.4 \\
\hline & 470.3 \\
\hline & 473.8 \\
\hline & $>500$ \\
\hline $\min$ & 197.8 \\
\hline $\max$ & 473.8 \\
\hline mean & 362.3 \\
\hline
\end{tabular}

* - homogenization towards gas phase

several cases, we found inclusions or whole assemblages that did not undergo homogenization at temperatures of up to $500^{\circ} \mathrm{C}$, and they displayed Brownian motion features. Therefore, their homogenization may occur in higher temperatures. In many crystals, decrepitation, with rapid jumps of crystals, occurred at temperatures exceeding $300^{\circ} \mathrm{C}$.

Solid and solid-gas inclusions are very often present in anhydrite crystals, in which three types that are clearly distinct as regards optical features and forms of occurrence are encountered. The first type forms compact, non-transparent concentrations whose shapes are irregular and round, with dimensions ranging from several tens of micrometres to $\sim 150 \mu \mathrm{m}$ (Fig. 6E). They are made of minerals with a short-columnar habit and dimensions of several micrometres.

The second type occurs as concentrations of individual transparent crystals characterized by a needle-like habit (Fig. $6 \mathrm{~F})$. Most often, these needle-like crystals spread in various directions from their common centre, and their length reaches up to $50 \mu \mathrm{m}$. Quite often, they are accompanied by irregular and small concentrations of the first type.

The third type of inclusions is most common and it consists of the inclusions of cylindrical, elongated and elliptical shape. Their dimensions reach from several to $>100 \mu \mathrm{m}$ (Fig. 7A). Locally, especially in the case of larger individuals, those inclusions are accompanied by small quantities of the liquid, gas or solid phases. These phases are characterized by other optical properties than those of the main mass of those inclusions. The inclusions are composed of transparent minerals demonstrating very intense interference colours under crossed polars (Fig. 7B). Some of this type of solid inclusion underwent characteristic transformations during microthermometric studies. Double refraction disappeared and the crystals filling the inclusion were clearly melting within the temperature range from 172.5 to $184^{\circ} \mathrm{C}$. That process was often accompanied by gaseous phase nucleation. Cooling of those inclusions below the observable melt temperatures caused crystallisation of the mineral. The mineral crystallised in the form of several small crystals (Fig. 7C, D) which did not fully fill the inclusion space. Most often, a bubble of the gas phase developed. During subsequent cooling, the bubble volume was reduced and the remaining section of the inclusion was filled by the liquid.

Less often, especially in large inclusions, we could also observe more complex transformations. During the melting processes of the double-refraction mineral, concurrent and rapid crystallisation occurred in several places of the isotropic mineral, in the form of cubes (Fig. 7E). Further heating caused very slow and gradual melting of those crystals, although they did not fully dissolve at temperatures up to $230^{\circ} \mathrm{C}$. Cooling of such inclusions down to a much lower temperature than the melting temperature of the original mineral filling the inclusion $\left(\sim 130^{\circ} \mathrm{C}\right)$, caused rapid crystallisation of another mineral with a different double refraction index (Fig. 7F).

\section{STRONTIUM CONTENT IN ANHYDRITE CRYSTALS}

Point chemical analysis was conducted on several anhydrite crystals. This revealed very high strontium contents ranging from 989 to $9597 \mathrm{ppm}$ with an average of $4244 \mathrm{ppm}$ and median of $4042 \mathrm{ppm}$. The strontium most often occurs in range $3000-6000 \mathrm{ppm}$ (Fig. 8A). In single anhydrite crystals the content of strontium is not uniform and does not show any obvious spacial pattern (Fig. 8B).

\section{DISCUSSION}

The development, and mainly the presence of the inclusions, indicate considerable thermal transformations affecting the salt rocks under discussion. Inclusions in halite, which can be recognized as primary owing to their spatial arrangement (e.g., Kovalevych et al., 2002; Kovalevych and Vovnyuk, 2010 with references therein), are rare. These inclusions differ from typical primary FIAs developed during sedimentation, with respect to the infill material. They display the presence of daughter minerals occurring in a proportional quantity with respect to volume. That phenomenon, similarly to the fixed proportion of gaseous to liquid phase in FIAs (e.g., Roedder, 1984a, b; Goldstein and Reynolds, 1994; Goldstein, 2001) indicates a homogeneous nature of brines from which halite crystallised and their saturated character. Consequently, the temperature of complete dissolution of those minerals, of $420^{\circ} \mathrm{C}$, indicates that halite crystallisation developed in high-temperature conditions. The occurrence of such daughter minerals as carnallite supports a considerable content of potassium and magnesium in the brines migrating within the salt dome. These minerals remained in an ionic condition during that migration and were later captured by halite in high-temperature conditions. Later, when the salt dome rocks were cooling down, carnallite crystallised in inclusions, in proportion to the reducing dissolution ratio for potassium-magnesium chlorides, with temperature drop. The mi- 

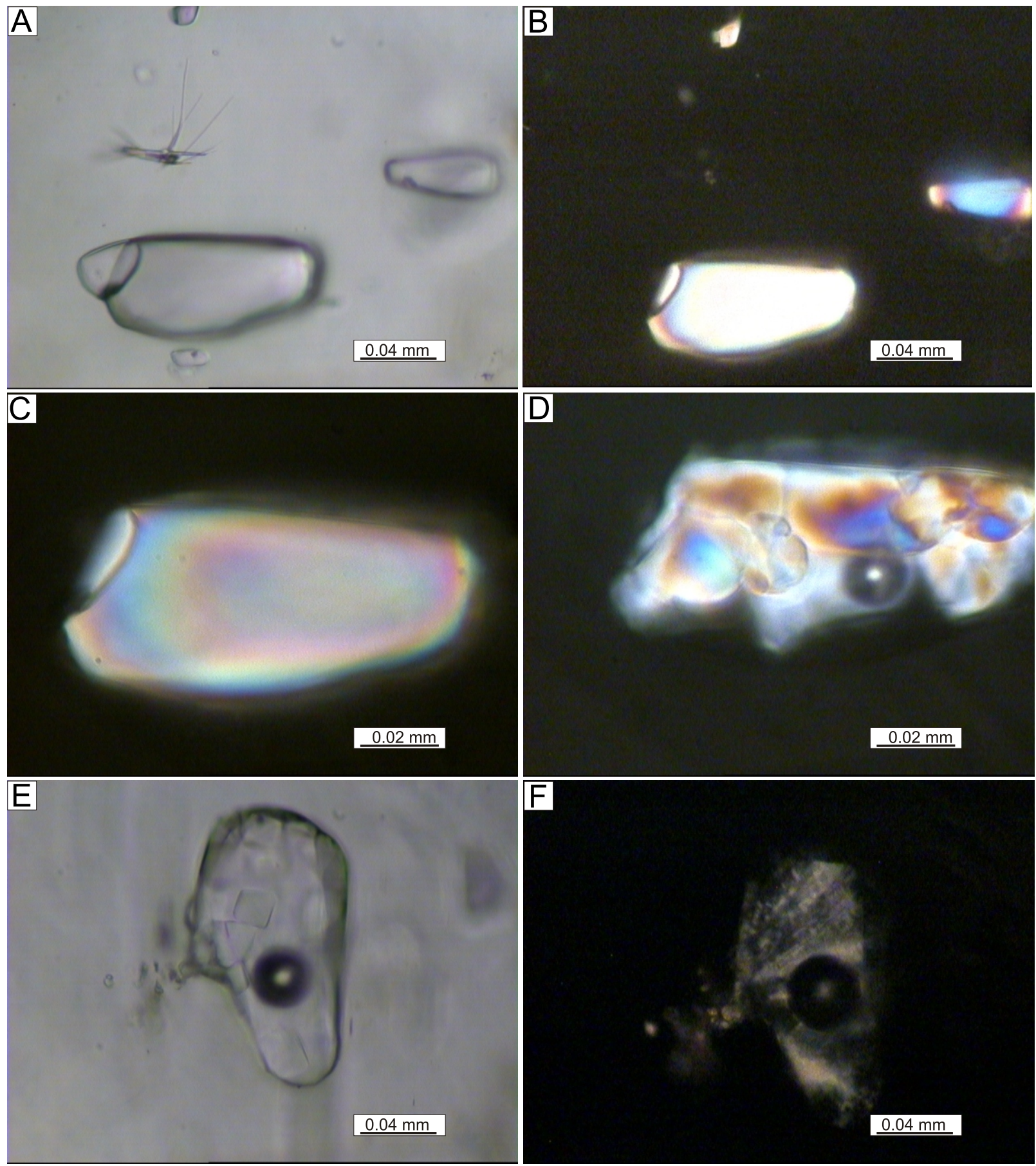

Fig. 7. Microscopic images of anhydrite crystals

A, B - ingrowths of transparent minerals, with cylindrical shapes; a large inclusion contains two components; the smaller part on the left contains an isotropic mineral and the larger one on the right clearly shows double refraction $(A-1 N, B-X N)$; C,$D-a$ large inclusion before heating $(C)$ and at the temperature of $174^{\circ} \mathrm{C}(\mathrm{D})$, where partial melting of an anisotropic mineral occurred, with gas phase nucleation; $\mathbf{E}$ - inclusion of the originally anisotropic mineral heated to a temperature of $230^{\circ} \mathrm{C}(1 \mathrm{~N})$; within that inclusion, cubic isotropic minerals can be seen; $\mathbf{F}$ - the same inclusion as in $\mathrm{E}$ after cooling below $130^{\circ} \mathrm{C}$; within that inclusion, at the place of melt, a mineral of other than original interference colours has crystallised $(\mathrm{XN})$, while isotropic minerals have remained

gration of carnalite in the form of relict crystals can be excluded because of their constant volumetric ratio to inclusion volume.

A similar origin can be assumed for halite that created the background for borates. Experimental studies on $\mathrm{NaCl}$ and $\mathrm{KCl}$ solutions at high temperatures and pressures (Sterner et al., 1988; Knight and Bodnar, 1989; Bodnar and Vityk, 1994) showed that halite dissolution rapidly increased above $100^{\circ} \mathrm{C}$.
Consequently, hot solutions were able to carry large quantities of dissolved sodium chloride. When such solutions are cooled, the excess of $\mathrm{NaCl}$ is released and it crystallises in the form of halite. Since the minimum temperature of daughter mineral dissolution was $420^{\circ} \mathrm{C}$, halite had to crystallise at much higher temperatures. 


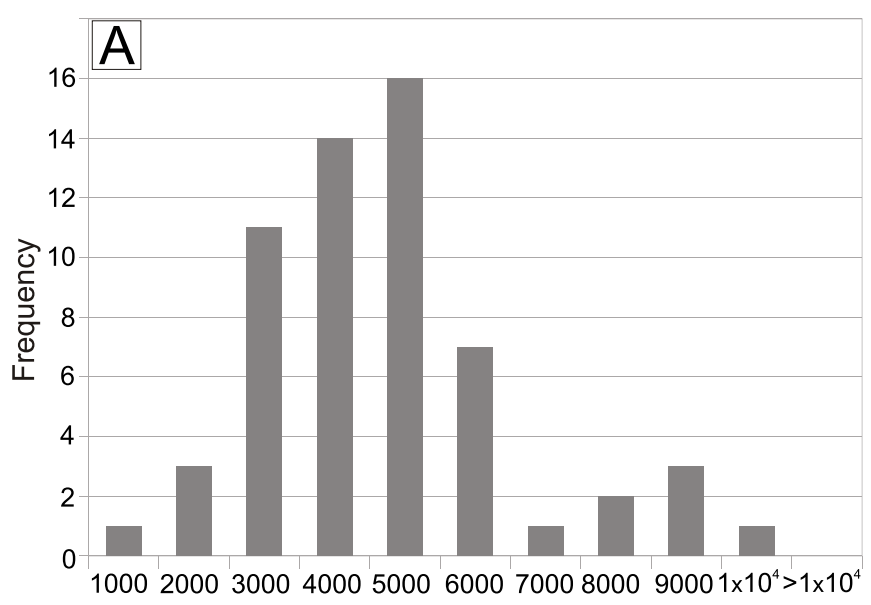

$\mathrm{Sr}[\mathrm{ppm}]$

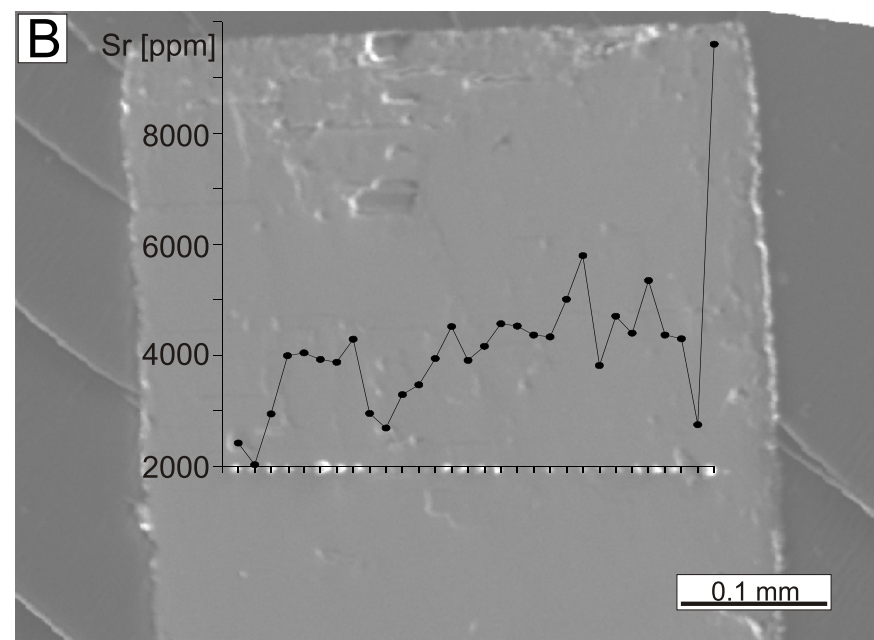

Fig. 8A - histogram of strontium contents in anhydrite crystals; B - distribution of strontium in anhydrite crust

The secondary inclusions occurring in the halite were highly diverse petrologically. They were filled with a gas phase which indicated considerable migration of gases after formation of the salt dome.

High temperature transformations of the salt rocks in which boracite and congolite crystals occurred were supported by petrological observations of fluid inclusions and microthermometric studies of anhydrite crystals. Differences between the congolite and boracite occurrence zones can be also observed. In the congolite zone, FIA bands locally occur in the central sections of crystals, composed of very small and densely packed inclusions. These inclusions show that the central sections of crystals were fragments which had originated in completely different conditions to those in which the external sections formed. The primary FIAs occur in the central sections, indicating that these parts of the crystals are relicts developed during anhydrite crystal sedimentation. Their different origin is supported by fluid inclusion distribution, which is similar to that of other occurrences of primary anhydrite (Toboła, 2014). Lack of primary FIAs in the anhydrite crystals from the boracite zone suggests that the transformation process was more complete than in the congolite zone, or that the chemical composition of brines was more prone to such far-reaching changes. However, the external sections of the anhydrite crystals, representing a completely different development, formed in other conditions. Those sections are distinguished by a very small quantity of fluid inclusions and numerous carnallite ingrowths. In that respect, they are similar to the anhydrite crystals from the boracite zone.

The microthermometric measurements give excellent evidence regarding the hydrothermal environment because they give the temperature of the solutions from which the minerals crystallised. Microthermometric measurements carried out on anhydrite crystals from the boracite zone indicate that these are either fragments or whole crystals which developed at temperatures from 200 to $>500^{\circ} \mathrm{C}$. Such high temperatures, with a wide range of variation at the same time, suggested a hydrothermal origin of the solutions from which anhydrite and borate minerals crystallised. In addition, the appearance of the inclusions that indicated homogenization towards the gas phase was consistent with a hydrothermal origin of the minerals, with locally developing "pockets" of diverse physical and chemical conditions (Diamond, 1990, 2001).

Solid inclusions were additional factors indicating diverse growth conditions of the anhydrite crystals. Detailed petrographic research on these solid phases will be published sepa- rately because microscopic observations in transmitted light could not identify such phases clearly. In the case of the third type of inclusions, with clear double refraction, our observations showed that we dealt with carnallite. The melting temperatures showed by our measurements $\left(172.5-184^{\circ} \mathrm{C}\right)$ were generally consistent with research conducted in DTA, DTG, and TG by Łaszkiewicz and Langier-Kuźniarowa (1966) and Emons and Fanghänel (1989). Those authors showed that the first endothermic effect associated with carnallite dehydratisation appeared at a temperature of $168^{\circ} \mathrm{C}$. Small temperature deviations resulted from experimental conditions because the inclusions constituted closed systems and also probably continent small quantities of residue brine. Water particles released during thermal transformations reacted with disintegrating carnallite to make carnallite melt.

The other important feature of carnallite thermal transformation, visible by microscopic observations, is the double nature of its melting during heating. The first is simple melting (gradual disappearance of carnallite) with gas phase nucleation. During subsequent cooling carnallite crystallised but some parts of the inclusions was still filled with a liquid and gas phase. The second path of thermal transformation depends on decomposition into sylvite and magnesium chloride solution. Further heating indicates that sylvite can partly dissolve in very dense $\mathrm{Mg}-\mathrm{Cl}$ solutions. Cooling of such inclusions make them filled with two minerals (sylvite and bischofite). Both pathways are generally in line with laboratory investigations on carnallite thermal decomposition described by e.g. Emons and Fanghänel (1989). The small differences between our observations and the laboratory tests noted above resulted from different conditions of carnallite decomposition. In the laboratory tests the carnallite decomposition was carried out in isobaric conditions (Emons and Fanghänel, 1989), while in the inclusions tested by us there was an isochoric condition. The other factor which has an influence on behaviour during carnallite decomposition is a small amount of brine in the inclusions.

The presence of such carnallite ingrowths within anhydrite, and in particular a large proportion of carnallite in respect of a liquid phase, suggested that potassium and magnesium chlorides occurred temporarily in brines in very large concentrations, and they may even have travelled in a melted form. The origin of the potassium and magnesium is connected with dissolution of primary K-Mg salt layers by migration of a hot solution.

Another important indicator of anhydrite formation is the strontium concentration. According to the many studies of $\mathrm{Sr}$ 
contents in anhydrite and the distribution coefficient, sedimentary anhydrites have diadochically included strontium in the range $\sim 1500$ to $\sim 2500$ ) ppm (e.g., Zherebtsova and Volkova, 1966; Kühn, 1968; Braitsch, 1971; Dean, 1978; Holser, 1979; Hryniv and Peryt, 2010). In the anhydrite studied the Sr contents are much higher than in common sedimentary anhydrite which show that the solution was enriched in strontium. Moreover, chemical analysis of single crystals (Fig. 8B) indicated a high variation of strontium contents in the solutions. A temporary surplus of strontium contents in the solutions resulted in precipitation of celestine.

\section{CONCLUSIONS}

Our analysis of salt rocks containing borate minerals have indicated that such formations were subjected to considerable thermal transformations. Minimum temperatures of the recrystallisation processes and transformations were determined based on the homogenization temperatures of fluid inclusions in the anhydrite which occurred together with boracite, as well as with reference to the melting of daughter minerals in primary FIAs in halite, containing congolite. These temperatures were in the range from $\sim 200$ to $>400^{\circ} \mathrm{C}$. The temperatures are similar to those observed in the transformation phases of boracite and congolite (Wachowiak and Toboła, 2014), showing the possibil- ity of direct crystallisation in a regular system at high temperatures (considering salt dome conditions). Consequently, conditions typical of hydrothermal systems are suggested by: high homogenization temperatures, a wide range of those temperatures, as well as the presence of inclusions, with their homogenization towards gas.

The occurrence of primary inclusions in the anhydrite crystals, separated from rock salts containing the congolite, indicated that the transformation process in this area was weaker than in boracite area. That does not mean that the temperatures were lower; they were rather associated with a diverse chemical composition of brines in both cases. This is supported by numerous transparent and non-transparent solid inclusions in anhydrite crystals from the borate zone, which are not present in the anhydrite separated from the rock salt containing congolite. However, the presence of carnallite ingrowths is a common feature, and this indicates a very large concentration of the potassium and magnesium chlorides in solution.

Acknowledgements. This research project was supported under Grant no 11.11.140.320 by the University of Science and Technology $(A G H)$ in Kraków. The authors would like to thank the reviewers, Prof. C. Helvacı and Prof. K. Jarmołowicz-Szulc and an anonymous reviewer, for constructive comments and suggestions which were helpful in preparing the final version of the paper.

\section{REFERENCES}

Benison, K.C., Goldstein, R.H., 1999. Permian paleoclimate data from fluid inclusions in halite. Chemical Geology, 154: 113-132.

Bodnar, R.J., Vityk, M.O., 1994. Interpretation of microthermometric data for $\mathrm{H}_{2} \mathrm{O}-\mathrm{NaCl}$ inclusions. In: Fluid Inclusions in Minerals, Methods and Applications (eds. B. De Vivo and M.L. Frezzotti): 117-130. Virginia Tech, Blacksburg, VA.

Borchert, H., Muir, R.O., 1964. Salt Deposits. The Origin, Metamorphism and Deformation of Evaporites. D. Van Nostrand Company, Ltd. London.

Braitsch, O., 1971. Salt Deposits their Origin and Composition. Springer, New York.

Burliga, S., Kolonko, P., Misiek, G., Czapowski, G., 1995. Kłodawa salt mine. In: Upper Rotliegend-Zechstein: Terrestrial-Marine Sedimentary Succession in Polish Permian Basin. XIII International Congress on Carboniferous-Permian, August 28 - September 2, 1995, Guide to Excursion A3, Kraków, Poland: $45-54$.

Burns, P.C., Carpenter, M.A., 1996. Phase transitions in the series boracite-trembatite-congolite: phase relations. Canadian Mineralogist, 34: 881-892.

Burns, P.C., Carpenter, M.A., 1997. Phase transitions in the series boracite-trembatite-congolite: an infrared spectroscopic study. Canadian Mineralogist, 35: 189-202.

Dadlez, R., 1989. Epicontinental Permian and Mesozoic basins in Poland (in Polish with English summary). Geological Quarterly, 33 (2): 175-198.

Dadlez, R., 2001. Mid-Polish Trough - geological cross-sections. Państwowy Instytut Geologiczny, Warszawa.

Dadlez, R., Narkiewicz, M., Stephenson, R.A., Visser, M.T.M., van Wees, J-D., 1995. Tectonic evolution of the Mid-Polish Trough: modelling implications and significance for Central European geology. Tectonophysics, 252: 179-195.
Dadlez, R., Iwanow, A., Marek, S., 1998. Mapa strukturalna kompleksu cechsztyńsko-mezozoicznego (in Polish). In: Mapa tektoniczna kompleksu cechsztyńsko-mezozoicznego na Niżu Polski, skala 1:500 000 (ed. R. Dadlez). Państwowy Instytut Geologiczny, Warszawa.

Dean, W.E., 1978. Trace and minor elements in evaporites. SEPM Short Course, 4: 86-104.

Diamond, L.W., 1990. Fluid inclusion evidence for P-V-T-X evolution of hydrothermal solutions in Late-Alpine gold-quartz veins at Brusson, Val d'Ayas, NW Italian Alps. American Journal of Science, 290: 912-958.

Diamond, L.W., 2001. Review of the systematics of $\mathrm{CO}_{2}-\mathrm{H}_{2} \mathrm{O}$ fluid inclusions. Lithos, 55: 69-99.

Emons, H.H., Fanghänel, T., 1989. Thermal decomposition of carnallite $\left(\mathrm{KCl} \cdot \mathrm{MgCl}_{2} \cdot 6 \mathrm{H}_{2} \mathrm{O}\right)$ - comparison of experimental results and phase equilibria. Journal of Thermal Analysis, 35: 2161-2167.

Garlicki, A., Szybist, A., 1986. Saline deposits of Polish Zechstein with potash salts (in Polish with English summary). Gospodarka Surowcami Mineralnymi, 2: 389-404.

Garlicki, A., Szybist, A., 1991. Trace elements in salts of Kłodawa Salt Mine (in Polish). Prace Specjalne PTMin., 1: 71-76.

Goldstein, R.H., 2001. Fluid inclusions in sedimentary and diagenetic systems. Lithos, 55: 159-193.

Goldstein, R.H., Reynolds, T.J., 1994. Systematics of fluid inclusions in diagenetic minerals. SEPM Short Course, 31: 1-199.

Holser, W.T., 1979. Trace elements and isotopes in evaporites. Mineralogical Society of America, Short Course Notes, 6: 295-346.

Hryniv, S., Peryt, T.M., 2010. Strontium distribution and celestite occurrence in Zechstein (Upper Permian) anhydrites of West Poland. Chemie der Erde, 70: 137-147.

Knight, C.L., Bodnar, R.J., 1989. Synthetic fluid inclusions: IX. Critical PVTX properties of $\mathrm{NaCl}-\mathrm{H}_{2} \mathrm{O}$ solutions. Geochimica et Cosmochimica Acta, 53: 3-8. 
Kovalevych, V., Vovnyuk, S., 2010. Fluid inclusions in halite from marine salt deposits: are they real micro-droplets of ancient seawater? Geological Quarterly, 54 (4): 401-410.

Kovalevych, V.M., Peryt, T.M., Carmona, V., Sydor, D.V., Vovnyuk, S.V., Halas, S., 2002. Evolution of Permian seawater: evidence from fluid inclusions in halite. Neues Jahrbuch für Mineralogie Abhandlungen, 178: 27-62.

Kovalevych, V.M., Marshall, T., Peryt, T.M., Petrychenko, O.Y., Zhukova, S.A., 2006. Chemical composition of seawater in Neoproterozoic: results of fluid inclusion study of halite from Salt Range (Pakistan) and Amadeus Basin (Australia). Precambrian Research, 144: 39-51.

Kovalevych, V., Paul, J., Peryt, T.M., 2009. Fluid inclusions in halite from the Röt (Lower Triassic) salt deposit in Central Germany: evidence for seawater chemistry and conditions of salt deposition and recrystallization. Carbonates and Evaporites, 24: $45-57$.

Krzywiec, P., 2004. Triassic evolution of the Kłodawa salt structure: basement-controlled salt tectonics within the Mid-Polish Trough (Central Poland). Geological Quarterly, 48 (2): 123-134.

Krzywiec, P., 2006. Structural inversion of the Pomeranian and Kuiavian segments of the Mid-Polish Trough - lateral variations in timing and structural style. Geological Quarterly, 50 (1) 151-168.

Krzywiec, P., Peryt, T.M., Kiersnowski, H., Pomianowski, P. Czapowski, G., Kwolek, K., 2017. Permo-Triassic evaporites of the Polish Basin and their bearing on the tectonic evolution and hydrocarbon system, an overview. In: Permo-Triassic Salt Provinces of Europe, North Africa and the Atlantic Margins Tectonics and Hydrocarbon Potential (eds. J.I. Soto, J.F. Flinch, G. Tari): 243-261, Elsevier.

Kucia Z., 1970. Nowe człony stratygraficzne cechsztynu w kopaln „Kłodawa” (in Polish). Przegląd Geologiczny, 18: 345-346.

Kühn, R., 1968. Geochemistry of German potash deposits. GSA Special Papers, 88: 427-504.

Łaszkiewicz, A., 1967. Salt minerals and rocks (in Polish with English summary. Prace Muzeum Ziemi, 11: 101-188.

Łaszkiewicz, A., Langier-Kuźniarowa, A., 1966. Application of the thermal analysis to the investigation of salt rocks (in Polish with English summary). Archiwum Mineralogiczne, 25: 131-159.

Petrychenko, O.Y., Peryt, T.M., 2004. Geochemical conditions of deposition in the Upper Devonian Prypiac' and Dnipro-Donets evaporite basins (Belarus and Ukraine). Journal of Geology, 112: 577-592.

Poborski, J., 1970. The Upper Permian Zechstein in the eastern province of Central Europe. In: Third Symposium on Salt (eds. J.L. Rau and L.F. Dellwig): 24-29. Northern Ohio Geological Society.

Poborski, J., 1971. Przewrót w poglądach na tektonikę wysadów solnych w regionie kujawskim (in Polish). Materiały z Kolokwium pod hasłem „Postęp w badaniach złóż surowców mineralnych" na temat geologii salinarnej w rejonie kujawskim. Wyd. AGH.
Poborski, J., 1974. On the tectogenesis of some diapiric salt structures in Central Poland, Upper Permian. In: Fourth Symposium on Salt (ed. A.H. Coogan): 267-269. Northern Ohio Geological Society.

Roedder, E., 1984a. Fluid inclusions. Mineralogical Society of America, Short Course Notes, 12: 1-644.

Roedder, E., 1984b. The fluid in salt. American Mineralogist, 69: 413-439.

Sonnenfeld, P., 1984. Brines and Evaporites. Academic Press, Orlando.

Stańczyk, I., 1970. Polyhalite in the salt mines of the Kujawy region (in Polish with English summary). Acta Geologica Polonica, 20: 805-821.

Stańczyk, I., 1971. Występowanie wtórnych agregatów mineralnych w kujawskiej serii solnej (in Polish). Sprawozdawania z Posiedzeń Komisji Naukowych. Oddz. PAN, w Krakowie, 15: 224.

Stańczyk-Stasik, I., 1976. Les dépots èpigénétiques dans les mines de sel de la région de Kujawy (in Polish with French summary). Prace Geologiczne, 90: 1-64.

Sterner, S.M., Hall, D.L., Bodnar, J.B., 1988. Synthetic fluid inclusions. V. Solubility relations in the system $\mathrm{NaCl}-\mathrm{KCl}-\mathrm{H}_{2} \mathrm{O}$ under vapor-saturated conditions. Geochimica et Cosmochimica Acta, 52: 989-1005.

Toboła, T., 2014. The influence of tectonics on petrological characteristics of anhydrite and anhydrite-halite intercalations in the Oldest Halite (Na1) (Zechstein, Upper Permian) of the Bądzów area (SW Poland). Geological Quarterly, 58 (3): 531-542.

Toboła, T., 2016. Inclusions in anhydrite crystals from blue halite veins in the Kłodawa Salt Dome (Zechstein, Poland). Geological Quarterly, 60 (3): 572-585.

Trusheim, F., 1957. Über Halokinese und ihre Bedeutung für die strukturelle Entwicklung Norddeutschlands. Zeitschrift der Deutschen Geologischen Gesellschaft, 109: 111-158.

Wachowiak, J., Pieczka, A., 2012. Congolite and trembatite from the Kłodawa Salt Mine, central Poland: record of the thermal history of the parental salt dome. Canadian Mineralogist, 50: 1387-1399.

Wachowiak, J., Toboła, T., 2014. Phase transitions in the borate minerals from the Kłodawa salt dome (central Poland) as indicators of temperature processes in salt diapirs. Geological Quarterly, 58 (3): 543-554.

Werner, Z., Poborski, J., Orska, J., Bąkowski, J., 1960. A geological and mining outline of the Kłodawa salt deposit (in Polish with English summary). Prace Instytutu Geologicznego, 30: 467-495.

Warren, J., 1999. Evaporites. Their Evolution and Economics. Blackwell Science Ltd., Oxford.

Zherebtsova, I.K., Volkova, N.N., 1966. Experimental study of microelement behavior during natural solar evaporation of the Black Sea water and Lake Sasyk-Sivash brine (in Russian). Geokhimiya, 7: 832-845 